\title{
Pengaruh Pad (Pendapatan Asli Daerah) Dan Kemandirian Keuangan Daerah Terhadap Alokasi Belanja Modal (Studi pada Pemerintah Kabupaten/Kota di Provinsi Sulawesi Tenggara)
}

\section{Oleh}

\author{
Nasrullah Dali ${ }^{1}$, Santiadji Mustafa ${ }^{2}$, Alifamin Farham ${ }^{3}$ \\ Email: alifaminfarham33@gmail.com
}

\begin{abstract}
This study aims to determine the effect of Locally Generated Revenue and Financial Capability toward Capital Expenditures Allocation of Cities in Southeast Sulawesi. The populations in this study were all cities and districts about 15 districts and 2 cities. The method that used in this study is multiple linear regression in t-test and F test under Statistical Package For Social Sciences (SPSS) 22nd version.

The result of this study shows Locally Generated Revenue has a positive and significant effect on capital expenditure. However, Capital Expenditures Allocation has a positive but not a significant effect on capital expenditure. The coefficient of determination test shows an $R$ Square value of 0.409, this shows that the ability of the independent variable able to explain the dependent variable with a coefficient of determination of $40.9 \%$, while the remaining $59.1 \%$ is explained by other variables that did not examine.
\end{abstract}

Keywords: Locally-Generated Revenue, Financial Capability, Capital Expenditures Allocation.

\section{PENDAHULUAN}

Otonomi daerah merupakan hak, wewenang, dan kewajiban daerah otonom untuk mengatur dan mengurus sendiri urusan pemerintahan dan kepentingan masyarakat setempat sesuai dengan peraturan perundang-undangan. Tujuan otonomi daerah adalah untuk mempercepat pertumbuhan ekonomi dan pembangunan daerah, mengurangi kesenjangan antara daerah dan meningkatkan kualitas pelayanan publik agar lebih efesien dan responsif terhadap kebutuhan, potensi maupun karateristik didaerah masing-masing. Otonomi daerah menghasilkan dampak yang beragam bagi perekonomian daerah juga berpotensi menimbulkan resiko fiskal.

Penyerahan berbagai kewenangan dari Pemerintah pusat ke Pemerintah daerah disertai dengan penyerahan dan pengalihan masalah pembiayaan. Dimana sumber pembiayaan yang penting bagi Pemda adalah Pendapatan Asli Daerah (PAD) yang komponennya adalah penerimaan yang berasal dari pajak daerah, retribusi daerah, hasil pengelolaan kekayaan daerah yang dipisahkan dan lain-lain PAD yang sah. Peningkatan PAD dalam jumlah yang besar diharapkan dapat mendorong akuntabilitas yang lebih, memperbaiki pembiayaan daerah, dan juga dapat memperkecil sumber pembiayaan yang berasal dari transfer Pemerintah pusat yang secara langsung meningkatkan kemandirian daerah. Setiap daerah mempunyai kemampuan keuangan yang tidak sama dalam mendanai kegiatan-kegiatannya, hal ini menimbulkan ketimpangan fiskal antara satu daerah dengan daerah lainnya.

Belanja modal merupakan belanja pemerintah daerah yang mempunyai pengaruh penting terhadap pertumbuhan ekonomi suatu daerah dan akan memiliki daya ungkit dalam menggerakkan roda perekonomian daerah (Kuncoro, 2004). Oleh karena itu, pemerintah daerah seharusnya melakukan pergeseran komposisi belanja yang nantinya dapat meningkatkan 
kepercayaan publik. Alokasi Belanja Modal ini dilandasi pada kebutuhan daerah akan sarana dan prasarana, baik untuk kelancaran pelaksanaan tugas pemerintah maupun untuk fasilitas publik. Penyusunan anggaran Belanja Modal pemerintah daerah, idealnya menggunakan sistem kebijakan investasi publik yang didasarkan pada kewajaran ekonomi, efisien dan efektif (value for money). Pengaruh dari PAD dalam alokasi Belanja Modal mempunyai peran yang penting dimana PAD yang di peroleh oleh daerah dapat dialokasikan ke Belanja Modal daerah tersebut agar daerah tidak bergantung lagi pada transfer dari pemerintah pusat tapi dapat menggunakan PAD sendiri untuk dapat membiayai kebutuhan belanja daerahnya, seperti penelitian yang dilakukan oleh Abdullah dan Halim (2004) dimana hasil penelitian tersebut menyimpulkan bahwa pendapatan asli daerah mempunyai berpengaruh positif terhadap belanja modal, temuan yang sama juga pada penelitian yang dilakukan oleh Harianto dan Adi (2007), Maharani (2007) maupun Putro (2011). Tidak hanya dari PAD Kinerja Keuangan juga mempunyai pengaruh terhadap belanja modal seperti penelitian yang dilakukan oleh Ardhini dan Handayani (2011) meneliti tentang pengaruh rasio kemandirian keuangan daerah terhadap belanja modal untuk pelayanan publik. Hasil penelitian menunjukkan bahwa rasio kemandirian berpengaruh terhadap belanja modal untuk pelayanan publik.

Tabel di bawah ini menjukan realisasi anggaran pendapatan Asli Daerah di Provinsi Sulawesi Tenggara pada tahun 2015, 2016, dan 2017.

Tabel 1.1 Presentase Realisasi Anggaran PAD Kabupaten/Kota di Provinsi Sulawesi Tenggara Tahun 2017

\begin{tabular}{|l|r|r|r|}
\hline \multicolumn{1}{|c|}{ Kabupaten/Kota } & Target & \multicolumn{1}{c|}{ Realisasi } & $\begin{array}{c}\text { Presentase } \\
\text { (\%) }\end{array}$ \\
\hline $\begin{array}{l}\text { Prov. Sulawesi } \\
\text { Tenggara }\end{array}$ & $737.568 .003 .285,00$ & $806,253,869,893.08$ & $109 \%$ \\
\hline Kab. Buton & $50.713 .093 .158,00$ & $48,262,953,828.76$ & $95 \%$ \\
\hline Kab. Konawe & $124.794 .614 .609,00$ & $97,586,836,006.97$ & $78 \%$ \\
\hline Kab. Kolaka & $124.794 .614 .609,00$ & $122,419,728,540.79$ & $98 \%$ \\
\hline Kab. Muna & $83,924,187,005.00$ & $81,248,091,528.00$ & $96 \%$ \\
\hline Kota Kendari & $408,475,410,745.00$ & $218,340,628,965.02$ & $53 \%$ \\
\hline Kota Bau-Bau & $86.960 .301 .451,00$ & $106,399,876,657.36$ & $122 \%$ \\
\hline Kab. Konawe Selatan & $109,347,568,864.00$ & $102,590,622,872.05$ & $93 \%$ \\
\hline Kab. Bombana & $62.155 .435 .018,00$ & $54,510,469,823.00$ & $87 \%$ \\
\hline Kab. Wakatobi & $44.819 .458 .348,00$ & $46,657,108,389.00$ & $95 \%$ \\
\hline Kab. Kolaka Utara & $58.217 .375 .488,00$ & $55,454,851,911.45$ & $113 \%$ \\
\hline Kab. Konawe Utara & $21.951 .759 .078,00$ & $25,002,200,734.00$ & $94 \%$ \\
\hline Kab. Buton Utara & $27.660 .740 .065,00$ & $26,049,368,584.00$ & $95 \%$ \\
\hline Kab. Kolaka Timur & $36.107 .387 .129,40$ & $34,381,357,159.00$ & $123 \%$ \\
\hline Kab. Konawe & $9.617 .037 .961,00$ & $11,906,780,679.00$ & $159 \%$ \\
\hline Kepulauan & $24.356 .440 .000,00$ & $38,810,929,616.00$ & $109 \%$ \\
\hline Kab. Muna Barat & $27.918 .392 .094,00$ & $30,693,747,186.00$ & $129 \%$ \\
\hline Kab. Buton Tengah & $6.557 .485 .799,00$ & $8,494,630,034.00$ & \\
\hline Kab. Buton Selatan & & & \\
\hline
\end{tabular}

Sumber: BPKAD PROV. SULTRA dan www.djpk.dpkeu.go.id.

Tabel 1.1 di atas merupakan angka realisasi pendapatan asli daerah Provinsi Sulawesi Tenggara pada tahun 2017 yang menyajikan angka target dan realisasinya. Dapat kita lihat dari anggaran target dan realisasi pada tahun 2017 di Provinsi Sulawesi Tenggara dimana angka 
realisasi PAD lebih tinggi dari angka targetnya hal ini menjelaskan bahwa pemerintah Provinsi Sulawesi tenggara berhasil mengupulkan PAD lebih dari yang di targetkan, begitu juga dengan daerah lainnya yang ada di Provinsi Sulawesi Tenggara seperti Kota Bau-Bau, Kabupaten Wakatobi, Kabupaten Konawe Utara, Kabupaten Konawe Kepulauan, Kabupaten Muna Barat, Kabupaten Buton Tengah, Kabupaten Buton Selatan yang memperoleh realisasi PAD lebih tinggi dari yang di targetkan di tahun 2017.

\subsection{Kajian Teori}

\section{KAJIAN PUSTAKA}

\subsubsection{Akuntansi Pemerintahan}

akuntansi pemerintah adalah sebagai pertanggung jawaban pemerintah untuk memberikan informasi keuangan secara lengkap, cermat dan tepat waktu dan juga dapat digunakan sebagai pengambilan keputusan serta penilaian kinerja pemerintahan dan untuk terselenggarakan pemeriksaan oleh aparat pengawas secara efektif dan efisien. Akuntansi keuangan daerah ini diperlukan sejalan dengan semangat otonomi daerah yang harus mengelola keuangan daerah secara terpisah dari pemerintah pusat. Untuk mencapai tujuan tersebut, pemerintah perlu mengatur standar akuntansi pemerintahan daerah agar dapat digunakan secara seragam di seluruh pemerintah daerah.

\subsubsection{Otonomi Daerah}

Tujuan utama penyelenggaraan otonomi daerah adalah untuk meningkatkan pelayanan publik dan memajukan perekonomian daerah pada dasarnya terkandung tiga misi utama pelaksanaan otonomi daerah yaitu meningkatkan kualitas dan kuantitas pelayanan publik dan kesejahtraan masyarakat, menciptakan efsiensi dan efektifitas pengelolaan sumber daya dan memberdayakan serta menciptakan ruang bagi masyarakat untuk berpartisipasi dalam proses pembanguna

\subsubsection{Anggaran Pendapatan dan Belanja Daerah (APBD)}

Menurut Undang-Undang nomor 33 tahun 2004 pasal 1 ayat 17 yang di maksud APBD adalah rencana keuangan tahunan pemerintah daerah yang di bahas dan di setujui bersama oleh pemerintah daerah dan DPRD, dan di tetapkan dengan peraturan daerah. Struktur APBD terdiri dari pendapatan daerah belanja daerah dan pembiayaan daerah, APBD disusun sesuia dengan kebutuhan penyelenggaraan pemerintah dan kemampuan pendapatan daerah.Dari data yang tertuang dalam APBD dapat dilihat kondisi keuangan Pemerintah daerah.Dari sisi pendapatan, dengan membandingkan Pendapatan Asli Daerah dengan total pendapatan dapat dilihat kemandirian suatu daerah, semakin tinggi nilainya semakin tinggi kemandirian keuangan daerahnya

\subsubsection{Belanja Daerah}

Menurut Peraturan Pemerintahan No. 58 Tahun 2005, Belanja daerah adalah kewajiban Pemerintah daerah yang diakui sebagai pengurangan nilai kekayaan bersih. Selanjutnya, dalam operasionalisasinya pada Anggaran Pendapatan dan Belanja Daerah (APBD), sebagaimana tertuang dalam Peraturan Menteri Dalam Negeri No. 25 Tahun 2009, belanja daerah merupakan bagian dari pengeluaran daerah, disamping pengeluaran pembiyaan daerah yang disusun dengan pendekatan prestasi kerja yang berorientasi pada pencapaian hasil dari input yang direncanakan agar pemerintah daerah berupaya menetapkan target capaian baik dalam konteks daerah, satuan kerja dan kegiatan sejalan denngan urusan yang menjadi kewenangannya. Dalam hal ini, belanja daerah merupakan perkiraan beban pengeluaran daerah yang dialokasikan secara adil dan merata agar relatif 
dapat dinikmati oleh seluruh kelompok masyarakat, khususnya dalam pemberian pelayanan umum.

Belanja daerah meliputi semua pengeluaran dari rekening kas umum daerah yang mengurangi ekuitas dana, merupakan kewajiban daerah dalam satu tahun anggaran dan tidak akan diperoleh pembayarannya kembali oleh daerah. Belanja daerah dirinci menurut urusan pemerintah daerah, organisasi, program, kegiatan, kelompok, jenis, obyek dan rincian obyek belanja. Belanja daerah dipergunakan dalam rangka mendanai pelaksanaan urusan pemerintahan yang menjadi kewenangan provinsi atau kabupaten/kota yang terdiri dari urusan wajib, urusan pilihan dan urusan yang penanganannya dalam bagian atau bidang tertentu yang dapat dilaksanakan bersama antara pemerintah dan pemerintah daerah atau antar pemerintah daerah yang ditetapkan dengan ketentuan perundangundangan.Dalam rangka memudahkan penilaian kewajaran biaya suatu program atau kegiatan, menurut kelompok belanja, belanja terdiri dari belanja tidak langsung dan belanja langsung.

\subsubsection{Pendapatan Asli Daerah (PAD)}

Pendapatan Asli Daerah adalah penerimaan daerah yang deperoleh atau di pungut dari sektor pajak daerah, retribusi daerah, hasil perusahaan milik daerah, hasil pengelolaan kekayaan daerah yang dipisahkan, lain-lain Pendapatan Asli Daerah. PAD yang tinggi merupakan impian yang harus diperjuangkan oleh setiap daerah untuk mencapainya. Tingginya PAD suatu daerah menggambarkan kemandirian suatu daerah otonom, sehingga tingkat ketergantungan Pemerintah Daerah akan bantuan dana dari Pemerintah Pusat semakin rendah.

\subsubsection{Kemandirian Keuangan Daerah}

Kemandirian Keuangan Daerah mencerminkan keadaan otonomi suatu daerah yang diukur dengan besarnya PAD terhadap jumlah total pendapatan daerah, sehingga memunculkan permasalahan suatu daerah yang dikatakan mandiri dapat meningkatkan jumlah belanja modal untuk pelayanan publik (Ardhini dan Handayani, 2011). Semakin tinggi rasio kemandirian mengandung arti bahwa tingkat ketergantungan daerah terhadap bantuan pihak eksternal pemerintah pusat dan provinsi semakin rendah (Mahmudi, 2010)

\subsubsection{Belanja Modal}

Belanja Modal menurut PP 71/2010 merupakan pengeluaran anggaran yang digunakan untuk memperoleh aset tetap dan aset lainnya.Belanja Modal mencakup Belanja Modal untuk memperoleh Tanah, Gedung dan Bangunan, Peralatan dan Aset Tak Berwujud. Belanja Modal dapat diklasifikasikan menjadi 2 (dua) kelompok yaitu Belanja Publik dan Belanja Aparatur. Belanja Publik adalah belanja yang manfaatnya dirasakan langsung oleh masyarakat, sedangkan Belanja Aparatur adalah hasil belanja pemerintah yang langsung dapat dirasakan oleh aparatur pemerintahan.

\subsection{Penelitian Terdahulu}

\begin{tabular}{|c|l|l|llr|}
\hline No & Peneliti & \multicolumn{2}{|c|}{ Judul } & \multicolumn{2}{c|}{ Hasil penelitian } \\
\hline & Sudarwadi & Pengaruh Pendapatan Asli Daerah, & menyimpulkan & bahwa \\
& $(2015)$ & Dana Alokasi Umum, dan Dana Alokasi & Pendapatan Asli & Daerah \\
& & Khusus terhadap Belanja Modal Daerah & (PAD) dan & Dana-2007 \\
1 & & (Studi Empiris Pada Kabupaten/Kota di & Alokasi & Umum & (DAU) \\
& & Provinsi Papua Barat Tahun 2014) & berpengaruh terhadap Belanja \\
& & & Modal, sementara & Dana \\
& & & Alokasi & Khusus & tidak \\
\hline
\end{tabular}




\begin{tabular}{|c|c|c|c|}
\hline & & & $\begin{array}{l}\text { berpengaruh terhadap Belanja } \\
\text { Modal. }\end{array}$ \\
\hline 2 & $\begin{array}{l}\text { Arbie } \\
\text { Gugus } \\
\text { Wandira } \\
(2013)\end{array}$ & $\begin{array}{l}\text { Pengaruh Pendapatan Asli Daerah } \\
\text { (PAD), Dana Alokasi Umum (DAU), } \\
\text { Dana Alokasi Khusus (DAK), Dan } \\
\text { Dana Bagi Hasil (DBH) Terhadap } \\
\text { Pengalokasian Belanja Modal Pada } \\
\text { Pemerintah Provinsi Se Indonesia. }\end{array}$ & $\begin{array}{l}\text { DAU dengan arah negatif, } \\
\text { DAK dan DBH berpengaruh } \\
\text { signifikan terhadap Belanja } \\
\text { Modal. Sedangkan PAD tidak } \\
\text { berpengaruh signifikan } \\
\text { terhadap Belanja Modal. } \\
\text { Secara simultan variabel } \\
\text { PAD, DAU, DAK, dan DBH } \\
\text { berpengaruh signifikan } \\
\text { terhadap Belanja Modal. }\end{array}$ \\
\hline 3 & $\begin{array}{l}\text { Ardhini } \\
\text { dan } \\
\text { Handayani } \\
(2011)\end{array}$ & 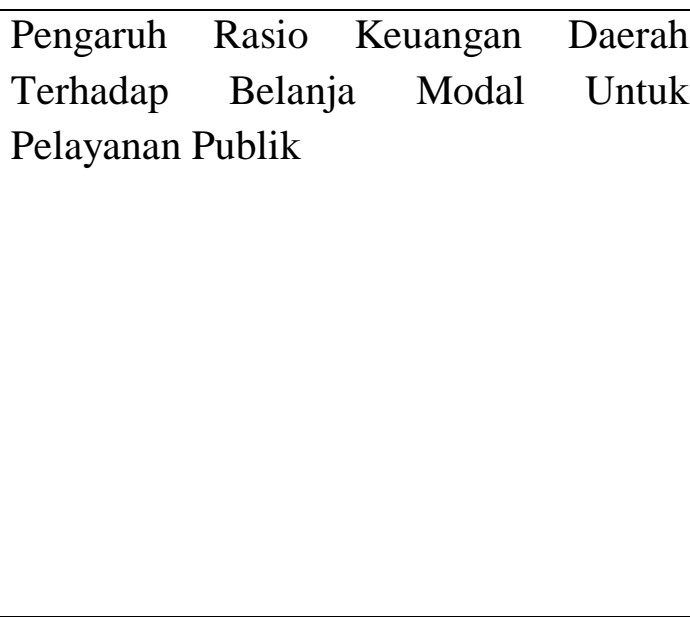 & $\begin{array}{l}\text { Hasil penelitian menunjukkan } \\
\text { bahwa rasio kemandirian } \\
\text { berpengaruh terhadap belanja } \\
\text { modal untuk pelayanan } \\
\text { publik, tingkat efektivitas } \\
\text { berpengaruh positif } \\
\text { signifikan terhadap belanja } \\
\text { modal, efisiensi berpengaruh } \\
\text { negatif namun signifikan } \\
\text { terhadap belanja modal untuk } \\
\text { pelayanan publik. }\end{array}$ \\
\hline 4 & $\begin{array}{l}\text { Sularso } \\
\text { dan } \\
\text { Restianto } \\
(2011)\end{array}$ & $\begin{array}{l}\text { Pengaruh Kinerja Keuangan Terhadap } \\
\text { Alokasi belanja Modal dan } \\
\text { Pertumbuhan Ekonomi Kabupaten/Kota } \\
\text { di Jawa Tengah }\end{array}$ & $\begin{array}{l}\text { Hasil penelitian menunjukkan } \\
\text { bahwa rasio ketergantungan } \\
\text { keuangan, rasio kemandirian } \\
\text { keuangan, rasio efektivitas } \\
\text { PAD berpengaruh terhadap } \\
\text { alokasi belanja modal serta } \\
\text { rasio desentralisasi } \\
\text { berpengaruh terhadap alokasi } \\
\text { belanja modal. }\end{array}$ \\
\hline 5 & $\begin{array}{l}\text { Hidayat } \\
(2013)\end{array}$ & $\begin{array}{l}\text { Pengaruh Kinerja Keuangan Daerah } \\
\text { Terhadap Alokasi Belanja Modal (Studi } \\
\text { pada Kabupaten dan Kota di Jawa } \\
\text { Timur). }\end{array}$ & $\begin{array}{l}\text { Hasil penelitian menunjukkan } \\
\text { bahwa rasio kemandirian, } \\
\text { rasio desentralisasi fiskal, } \\
\text { rasio efektefitas, efisiensi } \\
\text { berpengaruh signifikan } \\
\text { terhadap alokasi belanja } \\
\text { modal. }\end{array}$ \\
\hline
\end{tabular}




\section{Gambar 2.1 Kerangka Pikir Penelitian}

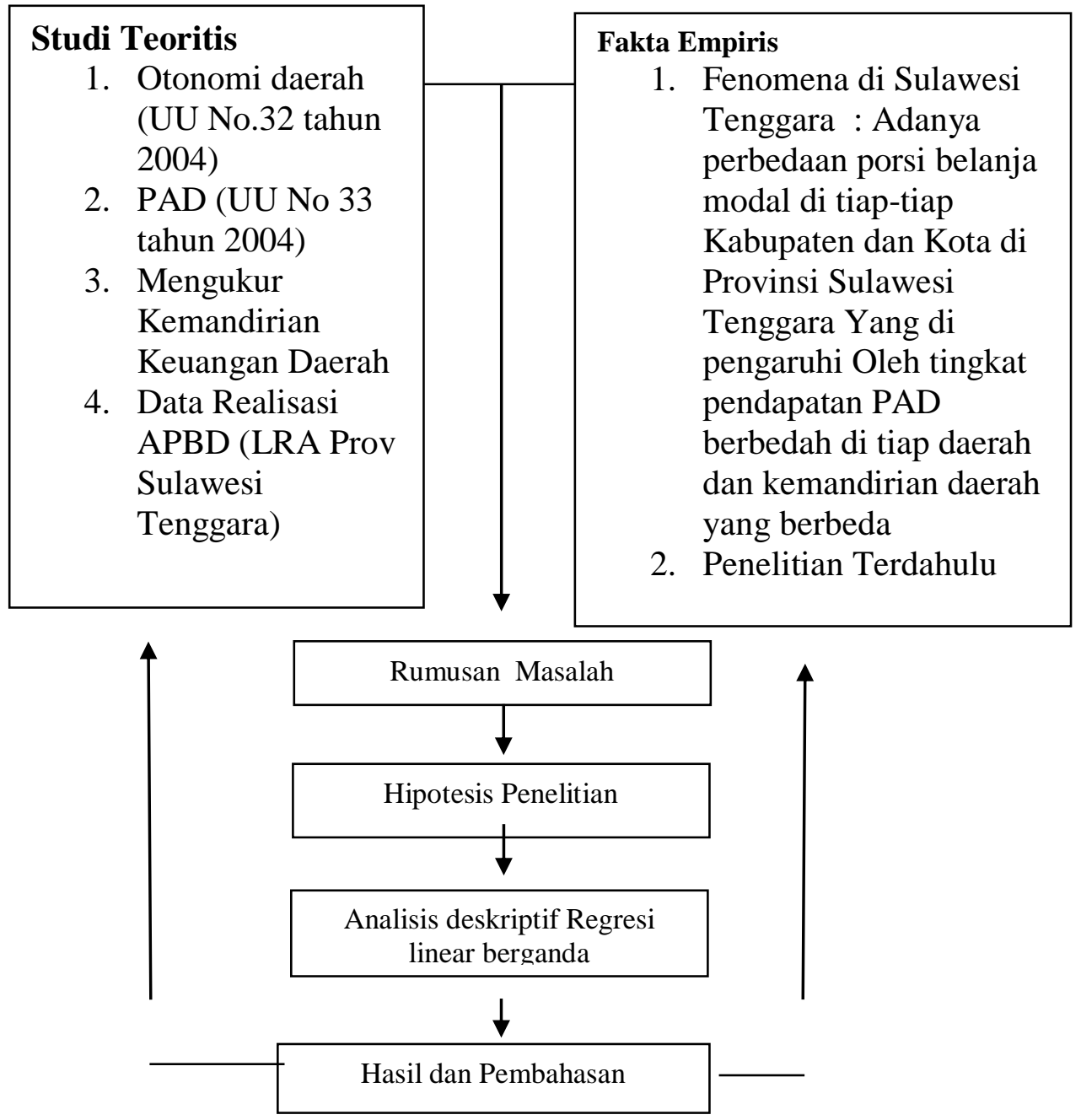

III. METODE PENELITIAN

Lokasi penelitian ini adalah Kabupaten/Kota di Provinsi Sulawesi Tenggara dan waktu penelitian ini dilakukan di tahun 2019. Objek penelitian ini adalah pengaruh Pendapatan Asli Daerah (PAD) dan Kemandirian Keuangan Daerah sebagai variabel independen dan Belanja Modal sebagai variabel dependen. Populasi adalah seluruh individu yang menjadi wilayah penelitian akan dikenai generalisasi (I.B. Netra, 1974 hal 10). Sedangkan Sampel adalah sebagian untuk diambil dari keseluruhan obyek yang diteliti dan dianggap mewakili seluruh populasi (Seokidjo. 2005 hal 79). Populasi yang digunakan dalam penelitian ini adalah pemerintah daerah Kabupaten/Kota di Provinsi Sulawesi Tenggara yang berjumlah 17 Kabupaten/Kota pada tahun 2015 - 2017.

Data yang dianalisis dalam penelitian ini adalah data sekunder yaitu data yang telah diolah lebih lanjut dan disajikan oleh pihak lain. Bersumber dari dokumen Laporan Realisasi APBD Kabupaten/Kota di Provinsi Sulawesi Tenggara yang diperoleh dari Badan Pengelola Keuangan dan Aset Daerah (BPKAD) SULTRA dan Situs Dirjen Perimbangan Keuangan Pemerintah Daerah di internet (www.djpk.depkeu.go.id). Dari Laporan Realisasi APBD ini diperoleh data mengenai jumlah realisasi anggaran Belanja Modal, dan data penerimaan Pendapatan Asli Daerah (PAD). 
Data yang digunakan dalam penelitian ini adalah data sekunder berupa Laporan realisasi APBD Pemerintah daerah dari ke sepuluh Kabupaten/Kota di provinsi Sulawesi Tenggara, dan yang diperoleh dari situs departemen keuangan Dirjen Perimbangan Keuangan Pusat dan Daerah (www.djpk.go.id). Data yang di gunakan dalam penelitian ini adalah data sekunder dan metode pengumpulan data sekunder ini dapat dilakukan dengan metode mengumpulkan, mencatat/mengambil data atau dokumen yang di perlukan untuk penelitian dari situs (www.djpk.depkeu.go.id) dan menghitung data-data yang berhubungan dengan penelitian. Penelitian ini menggunakan pendekatan kuantitatif. Secara umum, pendekatan kuantitatif lebih fokus pada tujuan untuk generalisasi dengan melakukan pengujian statistik dan steril dari pengaruh subjektif peneliti. Alat analisis yang digunakan dalam penelitian ini adalah analisis regresi berganda. Analisis regresi berganda adalah analisis mengenai beberapa variabel independen dengan satu variabel dependen.

\section{HASIL PENELITIAN DAN PEMBAHASAN}

\subsection{Gambaran Umum}

Sulawesi Tenggara dulunya merupakan nama salah satu Kabupaten di Provinsi Sulawesi Selatan dan Tenggara Sulselra dengan Bau-Bau sebagai Ibu Kota Kabupatennya pada saat itu, maka pada tahun 1964 yang di kenal dengan masa orde lama serta dengan kerja keras pemuda Sulawesi Tenggara maka ditetapkanlah provinsi ini sebagai Daerah Otonom berdasarkan Perpu No. 2 tahun 1964 dan UU No.13 dan pada saat itu Sulawesi Tenggara hanya memiliki empat Kabupaten yaitu : Kab. Kendari, Kab. Kolaka, Kab. Muna, dan Kab. Buton. Bau-Bau merupakan Ibu Kota Provinsi Sulawesi Tenggara, akan tetapi terjadi perpindahan Ibu Kota sehingga Ibu Kota Sulawesi Tenggara berada di Kota Kendari. Perpindahan ini dikarenakan kondisi Bau-Bau saat itu tidak begitu luas untuk pembangunan jangka pendek. Sehingga pada waktu itu diputuskan untuk mengganti Ibu Kota Sulawesi Tenggara di Kota Kendari sampai saat ini. Sehingga Masa Orde Baru yaitu Tahun 1995 dibentuk lagi satu Kota yaitu Kota Kendari, pemekaran dari Kabupaten Kendari, sekarang Kabupaten Konawe (3 Agustus 1995) dan Masa Era Reformasi Tahun 1999 Dibentuk lagi satu Kota Baru yaitu : Kota Bau-Bau, pemekaran dari Kabupaten Buton (21 Juni 2001) dan Masa Berikutnya Reformasi Terbentuklah beberapa Kabupaten baru.

\subsection{Hasil Penelitian}

Penelitian ini dilakukan di Provinsi Sulawesi Tenggara yang bertujuan untuk menganalisis pengaruh Pendapatan Asli Daerah, dan Kemandirian Keuangan Daerah terhadap Belanja Modal tahun 2015-2017. Data yang diperlukan berupa data realisasi Pendapatan Asli Daerah (PAD), dan Belanja Modal dari tahun 2015-2017 data diperoleh dari BPKAD PROV. SULTRA dan situs resmi direktorat Jendral Perimbangan Keuangan Pusat Dan Daerah (www.djpk.depkeu.go.id). Data yang sudah diperoleh diolah menggunakan metode regresi linear berganda dan uji hipotesis dengan aplikasi SPSS versi 22 (statistic product and service solution).

Pendapatan Asli Daerah memiliki peran yang cukup penting dalam menentukan kemampuan daerah untuk melakukan aktivitas pemerintah dan program-program pembangunan. Semakin besar Pendapatan Asli Daerah yang didapat maka semakin memungkinkan daerah tersebut untuk memenuhi kebutuhan belanjanya sendiri tanpa harus bergantung pada pemerintah pusat. Hal ini sejalan dengan pengertian otonomi daerah dimana otonomi daerah adalah hak, wewenang dan kewajiban daerah otonom untuk mengatur dan mengurus sendiri urusan pemerintah dan kepentingan masyarakat 
setempat sesuai dengan peraturan perundang-undangan tanpa ada campur tangan dari pemerintah pusat.

Pengaruh Kemandirian Keuangan Daerah terhadap Alokasi Belanja Modal dapat diketahui dengan pengujian statistik. Pengujian secara parsial dilakukan untuk mengetahui pengaruh dari variabel Kemandirian Keuangan Daerah terhadap Belanja Modal pada Kabupaten/Kota di provinsi Sulawesi Tenggara. Berdasarkan hasil analisis regresi yang menguji hipotesis menunjukkan nilai t hitung lebih kecil dari t table dengan tingkat signifikansi lebih besar, sehingga dapat disimpulkan hasil penelitian ini menunjukkan bahwa Kemandirian Keuangan Daerah berpengaruh positif namun tidak signifikan terhadap Belanja Modal.

Artinya tinggi rendahnya angka Kemandirian Keuangan Daerah tidak berpengaruh terhadap Belanja Modal atau ketika Kemandirian Keuangan Daerah mengalami peningkatan maka hal tersebut tidak berarti atau tidak memberi dampak yang besar terhadap alokasi Belanja Modal di Sulawesi Tenggara. Hal ini terjadi karena meningkatnya angka Kemandirian Keuangan Daerah tidak terlalu berdampak langsung kepada alokasi Belanja Modal dan juga angka kemandirian disetiap Kabupaten dan Kota di Provinsi Sulawesi Tenggara masih terbilang kecil atau masih belum mandiri sepenuhnya sehingga sekalipun ada peningkatan angka Kemandirian Keuangan Daerah hal itu tidak memberi dampak yang besar ke Alokasi Belanja Modal, hal ini dapat dilihat dari jumlah dana bantuan dari pusat yang masih begitu besar terutama untuk keperluan anggaran Belanja Modal seluruh daerah di Provinsi Sulawesi Tenggara.

Belanja Modal pada Kabupaten/Kota di Provinsi Sulawesi Tenggara pada tahun 20152017. Pada Tahun 2015 tiga daerah dengan tingkat Belanja Modal tertinggi adalah Kota Kendari pada posisi pertama kemudian Kabupaten Kolaka dan yang terakhir Kabupaten Kolaka Utara, dan untuk tiga daerah terendah tingkat Belanja Modal pada tahun 2015 adalah Kabupaten Muna barat, Kabupaten Buton Selatan, Kabupaten Buton Tengah. Untuk Tahun 2016 tiga daerah dengan tingkat Belanja Modal tertinggi adalah yang pertama Kota Kendari kemudian Kabupaten Muna, dan Kabupaten Kolaka Utara, sedangkan untuk daerah dengan Belanja Modal terendah adalah Kabupaten Buton Selatan, Kabupaten Kolaka Timur, dan Kabupaten Wakatobi. Untuk Tahun 2017 terjadi penuruan Belanja Modal pada Kabupaten Buton dan Kolaka pada tiga tahun penelitian yaitu tahun 2015-2017,.

\subsection{Pembahasan}

\subsubsection{Pengaruh Pendapatan Asli Daerah terhadap Alokasi Belanja Modal}

Pengaruh PAD terhadap Belanja Modal dapat diketahui dengan pengujian statistik. Pengujian secara parsial dilakukan untuk mengetahui pengaruh dari variabel PAD terhadap Belanja Modal pada Kabupaten/Kota di Provinsi Sulawesi Tenggara. Berdasarkan hasil analisis regresi yang menguji hipotesis menunjukkan nilai t hitung lebih besar dari $t$ table dengan tingkat signifikansi lebih kecil, sehingga dapat disimpulkan hasil penelitian ini menunjukkan bahwa PAD berpengaruh positif dan signifikan terhadap Belanja Modal. Artinya, jika PAD mengalami kenaikan maka mampu memberikan peningkatan terhadap Belanja Modal.

\subsubsection{Pengaruh Kemandirian Keuangan Daerah terhadap Alokasi Belanja Modal}

Pengaruh Kemandirian Keuangan Daerah terhadap Alokasi Belanja Modal dapat diketahui dengan pengujian statistik. Pengujian secara parsial dilakukan untuk mengetahui pengaruh dari variabel Kemandirian Keuangan Daerah terhadap Belanja Modal pada Kabupaten/Kota di provinsi Sulawesi Tenggara. Berdasarkan hasil analisis 
regresi yang menguji hipotesis menunjukkan nilai t hitung lebih kecil dari t table dengan tingkat signifikansi lebih besar, sehingga dapat disimpulkan hasil penelitian ini menunjukkan bahwa Kemandirian Keuangan Daerah berpengaruh positif namun tidak signifikan terhadap Belanja Modal.

\subsubsection{Pengaruh Dana Alokasi Umum dan Sisa Lebih Pembiayaan Anggaran terhadap Belanja Modal}

Hasil pengujian hipotesis menunjukkan bahwa variabel Pendaptan Asli Daerah dan variabel Kemandirian Keuangan Daerah berpengaruh dan signifikan terhadap Belanja Modal. Pengaruh tersebut dapat dilihat dari nilai $\mathrm{F}$ hitung lebih besar dari $\mathrm{F}$ table dengan tingkat signifikansi lebih kecil, sehingga dapat disimpulkan bahwa Pendapatan Asli Daerah dan Kemandirian Keuangan daerah secara simultan berpengaruh dan signifikan terhadap Belanja Modal. Hal tersebut menunjukkan jika Pendapatan Asli dan Kemandirian Keuangan Daerah secara bersama-sama mempunyai pengaruh terhdap alokasi Belanja Modal, menurut PP 71/2010 Penigkatan Belanja Modal berguna untuk memperoleh Tanah, Gedung dan Bangunan, Peralatan dan Aset Tak Berwujud yang memberikan manfaat lebih dari satu tahun.

Penelitian ini menunjukan bahwa Pendapatan Asli Daerah mempunyai pengaruh terhadap anggaran Belanja Modal dimana ketika terjadi peningkatan terhadap Pendapatan Asli Daerah maka akan mendorong peningkatan terhadap Belanja Modal hal ini di dukung oleh teori dari Ardhini (2011) yang menyatakan bahwa semakin tinggi pendapatan asli daerah di suatu daerah, maka Belanja Modal yang dilakukan pemerintah daerah juga semakin meningkat. Peningkatan terhadap Pendapatan Asli Daerah ini juga bisa membuat daerah itu menjadi mandiri untuk memenuhi kebutuhan daerahnya tanpa harus lagi menggunakan dana bantuan dari pusat seperti dana perimbangan, hal ini sesuai dengan prinsip otonomi daerah dimana daerah otonom diharapkan mampu untuk mengatur dan mengurus sendiri urusan pemerintah dan kepentingan masyarakat setempat sesuai dengan peraturan perundang-undangan tanpa ada campur tangan dari pemerintah pusat, agar tercapai tujuan meningkatkan kualitas dan kuantitas pelayanan publik dan kesejahteraan masyarakat, menciptakan efsiensi dan efektifitas pengelolaan sumber daya dan memberdayakan serta menciptakan ruang bagi masyarakat untuk berpartisipasi dalam proses pembangunan daerah.

Penelitian ini menjelaskan bahwa Kemandirian Keuangan Daerah merupakan kemampuan pemerintah dalam membiayai sendiri kegiatan pemerintahan, pembangunan dan pelayanan kepada masyarakat yang telah membayar pajak dan retribusi sebagai sumber pendapatan yang diperlukan daerah salah satunya adalah kegiatan Belanja Modal (Muliana,2009). Tingkat kemandirian keuangan daerah antara Pemerintah Pusat dan Daerah pada umumnya ditunjukkan oleh variabel-variabel Pendapatan Asli Daerah (PAD) terhadap Total Penerimaan Daerah (TPD), Rasio Bagi Hasil Pajak dan Bukan Pajak untuk Daerah (BHPBP) terhadap TPD, dan Rasio Sumbangan Bantuan Daerah (SBD) terhadap TPD. Untuk melihat kesiapan pemerintah daerah dalam menghadapi otonomi daerah khususnya di bidang keuangan, diukur dari seberapa jauh kemampuan pembiayaan urusan bila didanai sepenuhnya oleh PAD dan Bagi Hasil Daerah (Mulyanto,2007: 93).

Dalam mengukur tingkat kemandirian daerah ini, Muliana (2009) mengukurnya dengan membandingkan Pendapatan Asli Daerah dengan Total Pendapatan Asli Daerah yang diperoleh Daerah dalam Laporan Realisasi APBD. Tujuan kemandirian keuangan daerah mencerminkan suatu bentuk pemerintahan daerah apakah dapat menjalankan tugasnya 
dengan baik atau tidak. Menurut Widodo (dalam Halim, 2002) Rasio kemandirian menggambarkan ketergantungan daerah terhadap sumber dana ekstern. Semakin tinggi rasio kemandirian mengandung arti bahwa tingkat ketergantungan bantuan pihak ekstern (terutama pemerintah pusat dan provinsi) semakin rendah, dan demikian pula sebaliknya. Rasio kemandirian juga menggambarkan tingkat partisipasi masyarakat dalam pembangunan daerah. Semakin tinggi rasio kemandirian, semakin tinggi partisipasi masyarakat dalam membayar pajak dan retribusi daerah yang merupakan komponen utama pendapatan asli daerah.

\section{KESIMPULAN DAN SARAN}

\subsection{Kesimpulan}

Berdasarkan hasil penelitian yang telah di lakukan, dapat di tarik kesimpulan sebagai berikut:

1. Dari hasil analisis data secara parsial variabel Pendapatan Asli Daerah (PAD) berpengaruh dan signifikan terhadap Belanja Modal, menunjukkan bahwa semakin besar nilai Pendapatan Asli Daerah (PAD) dapat meningkatkan Belanja Modal atau ketika angka PAD meningkat sebanyak 5 maka belanja modal akan meningkat sebanyak 5 juga.

2. Dari hasil analisis data secara parsial variabel Kemandirian Keuangan Daerah berpengaruh namun tidak signifikan terhadap Belanja Modal, menunjukkan bahwa ketika nilai atau angka Kemandirian Keuangan Derah mengalami kenaikan maka hal tersebut tidak berarti atau tidak terlalu berpengaruh terhadap alokasi belanja Modal.

3. Dari hasil analisis data secara simultan variabel Pendapatan Asli Daerah (PAD) dan Kemandirian Daerah secara bersama-sama berpengaruh positif dan signifikan terhadap variabel dependen yaitu Belanja Modal.

\subsection{Saran}

Berdasarkan kesimpulan, adapun saran-saran yang dapat peneliti ajukan dan berikan sehubungan dengan hasil penelitian ini. Untuk memperbaiki penelitian selanjutnya, sebagai berikut:

1. Bagi pihak Pemerintah Daerah, dalam upaya meningkatkan Belanja Modal sebaiknya lebih memperhatikan tingkat Pendapatan Asli Daerah (PAD) dan Kemandirian Keuangan Daerah. Hal itu penting karena peningkatan PAD mempunyai dampak yang baik untuk Belanja Modal dimana ketika terjadi peningkatan terhdap PAD maka Belanja Modal juga akan meningkat, begitu juga dengan angka Kemandirian Keuangan Daerah dimana ketika angka kemandirian daearah tinggi hal itu menggambarkan bahwa daerah tersebut sudah bisa mandiri dan sudah dapat menjalakan prinsip otonomi daerah yang mana daerah dapat membiayai keperluan daerahya sendiri seperti untuk keperluan belanja modal dan tidak bergantung lagi dari bantuan dana dari pusat. Kedua variable tersebut terbukti berpengaruh terhadap Belanja Modal sesuai dengan hasil penelitian ini.

2. Bagi peneliti selanjutnya, diharapkan dapat membuktikan hasil akhir dari hipotesis yang ditolak apakah memang terbukti atau tidak. Selain itu diharapkan dapat meneliti dengan variabel-variabel lain diluar variabel ini agar memperoleh hasil yang lebih bervariatif yang dapat menggambarkan hal-hal apa saja yang dapat berpengaruh terhadap Belanja Modal. Penelitian ini masih terdapat keterbatasan maka diharapkan 
lagi penelitian selanjutnya dapat mengganti variable yang ada dan atau menambahkan variable lain yang mempengaruhi Belanja Modal.

\section{DAFTAR PUSTAKA}

Andreas M. Pelealu. 2013. Pengaruh Dana Alokasi Khusus (DAK), Dan Pendapatan Asli Daerah (PAD) Terhadap Belanja Modal Pemerintah Kota Manado Tahun 2003-2012. Denpasar: Jurnal EMBA 1197 Vol.1 No.4

Ardhini. 2011. Pengaruh rasio keuangan daerah terhadap belanja modal untuk pelayanan public dalam prespektif teori keagenan (studi pada kabupaten dan kota di jawa tengah). Skripsi,Universitas Diponegoro, Semarang.

Bastian, 2006.Akuntansi Sektor Publik, Erlangga, Surabaya.

Fajar Hidayat, Mochamad. 2013. Analisis Pengaruh Kinerja Keuangan Daerah Terhadap Alokasi Belanja Modal (Studi pada Kabupaten dan Kota di JawaTimur). Jurnall lmiah. Fakultas Ekonomi dan Bisnis Universitas Brawijaya. Malang.

Halim, Abdul \& Syam,Kusufi. 2012. Akuntansi Sektor Publik :teori, konsep dan aplikasi. Jakarta.Salemba Empat.

Halim.Abdul. 2004. Akuntansi Sektor Publik: Akuntansi Keuangan Daerah. Penerbit Salemba Empat. Jakarta

Halim, Abdul. 2002. Seri Akuntansi Sektor Publik-Akuntansi Keuangan Daerah. Jakarta, Salemba Empat.

Halim,Abdul 2012. Akuntansi Sektor Publik Akuntansi Keuangan Daerah. Edisi 4.Penerbit Salemba 4. Jakarta.

Hariani.Yuli. 2010. "Pengaruh Dana Alokasi Umum (DAU) dan PendapatanAsli Daerah (PAD) Terhadap Belanja Langsung Pemerintah Kabupaten/Kota di Sumatera Barat", Skipsi,Universitas Sumatera Utara Fakultas Ekonomi, Medan.

Kurniawan, D. 2010. Pengaruh Kinerja Keuangan terhadap Pertumbuhan Ekonomi Kota/Kabupaten di Sumatera Barat dalam era Otonomi Daerah. Tesis. Universitas Andalas.

Kusnandar dan Dodik Siswantoro, 2012. Tujuan ekonomi yang hendak dicapai melalui desentralisasi adalah mewujudkan kesejahteraan melalui penyedia pelayanan publik yang lebih merata dan memperpendek jarak antara penyedia layanan public dan masyarakat lokal.

Mardiasmo. 2004. Otonomi dan Manajemen Keuangan Daerah. Yogyakarta.

Mentayani, Ida dan Rusmanto. 2013. Pengaruh Pendapatan Asli Daerah, Dana Alokasi Umum dan Sisa Lebih Pembiayaan Anggaran terhadap Belanja Modal pada kota dan Kabupaten di Pulau Kalimantan. Jurnal Infestasi vol. 9 no. 2: 91- 102.

Mudrajad Kuncoro. 2004. Metode Kuantitatif : Teori dan Aplikasi untuk Bisnis dan Ekonomi. Yogyakarta : UPP AMP YKPN.

Nordiawan.Dedi 2008.AkuntansiPemerintahan, Jakarta : Salemba Empat.

Peraturan Menteri Dalam Negeri Nomor 59 Tahun 2007 tentang Pedoman Pengelolaan Keuangan Daerah (PerubahanPertamaPermendagri No 13 Tahun 2006).

Puspita, D. 2014. Pengaruh kinerja keuangan terhadap alokasi belanja modal (studi empiris pada provinsi jawa barat tahun 2009-2012). Universitas gunadarma.

Saragih, Juli Panglima. 2003. Desentralisasi Fiskal dan Keuangan Daerah dalam Otonomi. Jakarta: Penerbit Ghalia Indonesia. 
Sularso, H., danRestianto, Y. 2011. Pengaruh Kinerja Keuangan terhadap Alokasi Belanja Modal dan Pertumbuhan Ekonomi Kabupaten/Kota di Jawa Tengah. Media Riset Akuntansi, Vol. 1 No. 2 Agustus 2011.

Sularso, H., Restianto, Y.E. 2011.PengaruhN Kinerja Keuangan Terhadap Alokasi Belanja Modal dan Pertumbuhan Ekonomi Kabupaten/Kota di Jawa Tengah. Media Riset Akuntansi, Vol.1 No.2: 109-124.

Undang-undang Republik Indonesia Nomor 23 Tahun 2014 tentang Pemerintah Daerah.

2005. Peraturan Pemerintah Nomor 55 Tahun 2005 tentang Dana Perimbangan.

2010. Peraturan Pemerintah Nomor 71 Tahun 2010: Standar Akuntansi Pemerintahan Berbasis Akrual.

2006. Peraturan Menteri Dalam Negeri Nomor 13 Tahun 2006 Tentang Pedoman Pengelolaan Keuangan Daerah.

2005. Peraturan Pemerintah Nomor 58 Tahun 2005 tentang Pengelolaan Keuangan Daerah

2009. Peraturan Menteri Dalam Negeri No 25 Tahun 2009 yang berisi Pedoman Penyusunan APBD Tahun 2010,

Undang-Undang No. 32/2004 tentang Pemerintahan Daerah (revisi atas UU No. 22/1999).

Undang-UndangNo.34/2000 tentang Perubahan atas Undang-undang Republik Indonesia No. 18 tahun 1997 tentang Pajak dan Retribusi Daerah.

www.djpk.depkeu.go.id

BPKAD PROVINSI SULAWESI TENGGARA 2019 